\title{
Membangun Kemampuan Skill Analisis Pelacakan Kerusakan dan Perbaikan Laptop bagi siswa SMK
}

\author{
Agus Efendi, Basori, Endar Suprih Wihidayat \\ Dosen Pendidikan Teknik Informatika dan Komputer, UNS \\ agusuns@yahoo.com
}

\begin{abstract}
Abstrak
Pelatihan kemampuan hard skill dan soft skill siswa SMK melalui analisis pelacakan dan perbaikan laptop bertujuan : 1) Membangun kompetensi skill siswa SMK baik hardware maupun software, 2) Pemberian kesempatan siswa SMK untuk berlatih dan eksperimen, 3) Mengakomodasikan kesulitan belajar siswa SMK melalui mekanisme umpan balik, 4) Memberikan pelatihan analisis pelacakan kerusakan dan perbaikan laptop yang mudah dipahami selaras dengan kompetensi dasar bidang keahlian elektronika/Komputer. Lama pelatihan selama 18 jam tatap muka dan 17 jam penugasan. Pelaksanaan kegiatan pelatihan diikuti oleh 20 siswa dari SMK Adi sumarmo colomadu dan SMKN Muhammadiyah 3 Karanganyar. Peserta pelatihan memiliki inovasi kreativitas berpikir yang baik dengan rerata skor 3,8 atau $75 \%$. Keterampilan praktek yang dimiliki peserta pelatihan mencapai rerata skor 3,6 atau 72\%. Program Pelatihan ini sangat bermanfaat terutama dalam meningkatkan kemandirian dengan baik mencapai rerata skor 4,0 atau $80 \%$. Secara keseluruhan evaluasi pelaksanaan kegiatan pelatihan berlangsung secara baik mencapai rerata skor 3,9 atau $77,1 \%$. Selain itu penilaian terhadap instruktur pelatihan sebagai nara sumber atau instruktur mencapai rerata skor 4,2 atau 83,2 \% dengan kategori sangat baik. Dapat disimpulkan bahwa program pelatihan analisis kerusakan dan perbaikan laptop dapat memberikan manfaat yang sangat besar bagi siswa SMK. Kegiatan pelatihan ini sangat baik untuk memberikan tambahan kemampuan skill dan kompetensi lulusan SMK khususnya di bidang laptop yang siap bersaing di dunia kerja dan mandiri.
\end{abstract}

Kata Kunci: pelatihan, membangun kemampuan Skill siswa SMK, perbaikan Laptop

\begin{abstract}
Training the ability of hard skills and soft skills of vocational students through the analysis of tracking and laptop repair aims: 1) Establish competency skills of vocational students in both hardware and software, 2) Providing the opportunity of vocational students to practice and experiment, 3) Accommodate learning difficulties vocational students through a feedback mechanism behind, 4) Providing training tracking analysis and repair of laptops are easily understood in harmony with the basic competencies of expertise electronics / computer. The duration of training for 18 hours face-to-face and 17 hours of assignment. Implementation of the training activities attended by 20 students of SMK Adi SUMARMO Colomadu and SMK Muhammadiyah 3 Karanganyar. Participants have creativity to think of a good innovation with an average score of 3.8 or $75 \%$. Practice skills that owned by trainee achieving mean score of 3.6 or $72 \%$. This training program is particularly useful in improve independence well achieved a score of 4.0 or $80 \%$. Overall evaluation of the training activities take place either reaches an average score of 3.9 or $77.1 \%$. In addition an assessment of the training instructor or instructor as a resource to achieve an average score of 4.2 or $83.2 \%$ with very good category. It can be concluded that the training program analysis of the damage and repair the laptop can provide enormous benefits for vocational students. This training is excellent to provide additional capabilities and competence of graduates of vocational skills, especially in the field of laptop that is ready to compete in the world of work and self-contained.
\end{abstract}

Keywords : Training, Build Capatibility Skill of Vocational Student, Laptop Repairs 


\section{Pendahuluan}

Masalah krusial yang harus segera ditangani pada pendidikan kejuruan adalah masalah akses, relevansi, kualitas, daya saing dan pemerataan pendidikan. Masalah ini tentunya dijabarkan pemerintah melalui berbagai misinya. Guna merealisasikan hal tersebut arah pembangunan pendidikan nasional pada tahun 2015-2019 difokuskan pada daya saing regional. Guna menghasilkan lulusan SMK yang mempunyai daya saing yang tinggi, terserapnya lulusan di dunia kerja dengan persentase yang tinggi, bukanlah hal yang mudah. Untuk hal tersebut perlu strategi, dan upaya yang serius melalui berbagai bentuk dan cara. Salah satu upaya yang mendesak dilakukan adalah menciptakan kualitas output lulusan SMK yang berkompeten. Perkembangan informatika dan komputer sebagai salah satu disiplin ilmiah telah mengalami kemajuan pesat. Perkembangan dalam bidang perangkat keras yang terwujud dalam berbagai jenis komputer, mulai dari mainframe hingga notebook atau laptop. Beberapa hal yang tidak dapat dihindari seiring dengan banyaknya penggunaan laptop yaitu adanya kerusakan. Laptop menjadi bagian teknologi komputer yang telah berkembang dengan pesatnya diberbagai bidang. Teknologi komputer (Laptop) memungkinkan siswa Sekolah Menengah Kejuruan (SMK) bidang elektronika dan komputer seharusnya kompeten dibidangnya untuk bersaing di dunia usaha bila sudah lulus kelak. Calon lulusan SMK khususnya bidang elektronika dan komputer tidaklah cukup berbekal dari materi yang disampaikan di sekolah saja, tanpa diberi kemampuan skill berupa pengalaman praktek nyata dan kontekstual. Secara empirik siswa SMK dituntut memiliki kemampuan skill khususnya kemampuan dibidang analisis pelacakan kerusakan dan perbaikan laptop.

Untuk menciptakan kompetensi siswa SMK dibidang teknisi laptop yang inovatif dan handal dibutuhkan kemampuan hard skill dan soft skill yang diukur dari kemampuan mereka dalam menganalisis dan melacak kerusakan sampai kepada perbaikan laptop. Minimnya skill dan pemahaman siswa SMK menjadi alasan penting untuk dilakukan kegiatan program pengabdian masysrakat sebagai upaya membangun kemampuan skill mereka agar mampu menganalisis pelacakan kerusakan dan perbaikan laptop. Pada sisi lain, teknologi informatika dan komputer khususnya Laptop yang terus berkembang dan inovatif menciptakan peluang kerja baru bagi masyarakat. Teknologi informatika dan komputer ini seakan sudah melekat dan menjadi kebutuhan bagi masyarakat. Berbagai merk Laptop telah berkembang seiring dengan kemajuan teknologinya. Alat ini tidak saja di gunakan sebagai pengolah data tetapi juga dapat digunakan sebagai perangkat dengan berbagai kegunaan terutama sebagai media pendidikan. Dengan melihat besarnya segmen pasar dari Laptop tentunya terdapat peluang usaha yang besar. Khususnya pada masalah perawatan dan perbaikan, bahwa yang terjadi di lapangan adalah masih minimnya tenaga ahli profesional dibidang laptop. Hal tersebut disebabkan oleh minimnya bekal kompetensi keahlian yang masih rendah.

Melihat kenyataan ini perlu adanya upaya dan dukungan pemerintah melalui Dinas Pendidikan Nasional seperti program-program dari Pendidikan Luar Sekolah (PLS) berupa kegiatan program Pelatihan dianggap sangatlah tepat dan sesuai dengan keadaan dunia kerja yang ada. Sebagaimana kita ketahui bahwa tingkat daya saing bangsa ini masih sangat rendah. Oleh karena itu diperlukan upaya-upaya untuk meningkatkan kualitas Sumber Daya Manusia (SDM) sebagai upaya program pengentasan pengangguran. Melihat perkembangan pertumbuhan peduduk di wilayah Kota Surakarta dan sekitarnya serta kurangnya pendidikan ketrampilan tertentu kita dapat menarik suatu gambaran yang kongkrit utamanya hingga menimbulkan berbagai macam persoalan di 
lapangan. Hal tersebut memberi dampak pengaruh terhadap : (1) banyaknya masyarakat di usia produktif yang tidak dapat memperoleh pengetahuan yang layak, (2) banyaknya masyarakat yang tidak dapat mengisi atau mengambil peluang kerja baik mandiri maupun kelompok yang disebabkan sangat terbatasnya keterampilan yang dimiliki, (3) banyaknya masyarakat tidak mendapatkan keterampilan yang cukup untuk memasuki dunia kerja.

Berdasarkan fakta empiris di atas, bahwa lulusan siswa SMK khususnya bidang keahlian komputer dan elektronika dituntut memiliki kompetensi yang siap bersaing di dunia kerja dan usaha mandiri. Program reguler di SMK belum cukup menjamin bekal kemampuan lulusan yang kompeten. Salah satu langkah strategis yang perlu diambil adalah peningkatan kualitas kompetensi SDM. Langkah yang strategis adalah memberikan pelatihan berupa penguatan ketrampilan tambahan kepada mereka yang berusia produktif. Peningkatan kualitas kompetensi SDM yang dimulai sejak dini dapat berpengaruh pada daya saing individu itu sendiri. Salah satu ketrampilan yang akan diberikan kepada siswa SMK bidang elektronika dan komputer adalah pelatihan membangun kemampuan skill dibidang hardware dan software melalui kemampuan analisis pelacakan dan perbaikan laptop. Program kegiatan ini dapat memberikan bekal keahlian tertentu yang mengarah ke profesi yang jelas, sehingga peserta benar-benar siap berkarir setelah lulus nanti. Program pelatihan ini sangat layak dan berpotensi mengatasi masalah pengangguran di masyarakat. Program pelatihan ini memiliki nilai tepat guna, tepat sasaran dan strategis dalam upaya miningkatkan Sumber daya manusia dengan berpegang teguh pada prinsipprinsip antara lain adalah : (1) pelaksanaan program pendidikan dan pelatihan berorientasi pada kebutuhan pasar kerja dan peluang usaha, (2) sesuai analisis situasi mengenai permasalahan yang dihadapi oleh masyarakat atau mitra SMK, (3) Peserta Pelatihan lulusan SMK mampu bersaing dalam mencari pekerjaan ataupun berwirausaha, sehingga mereka mempunyai mata pencaharian sesuai dengan keterampilan yang dimiliki. Sasaran kegiatan pelatihan kemampuan hard skill dan soft skill siswa SMK melalui analisis pelacakan dan perbaikan laptop adalah: 1) memiliki tujuan instruksional khusus, 2) mengarah pada pencapaian akhir kompetensi pembelajaran, 3) berfokus pada pemberian kesempatan siswa SMK untuk berlatih dan eksperimen, 4) mengakomodasikan kesulitan belajar siswa SMK melalui mekanisme umpan balik, 5) substansi materi workshop dikemas dalam sebuah modul bahan ajar pelatihan yang mudah dipahami selaras dengan kompetensi dasar bidang keahlian komputer. Program kegiatan pelatihan ini memenuhi kaidah yang runtut, sistematis dan rasional yang mampu menggambarkan tujuan akhir workshop, topik bahasan, sub topik bahasan, serta kriteria indikator penilaian hasil pelatihan.

Hakikat Model Pelatihan Snelbecker (1974:32) menyatakan : "A model is a concretization of a theory which is meant to be analogous to or representative of the processes and variables involved in the theory". Sebuah model dibangun dari serangkaian dalil-dalil aras abstraksi rendah (sehingga lebih konkrit); sedangkan teori menurut Joyce, Weil \& Calhoun (2011), dalam terminologi yang lebih spesifik (model pembelajaran) memberikan batasan bahwa model adalah seperangkat komponen yang saling terkait diatur dalam urutan yang memberikan pedoman untuk mewujudkan tujuan tertentu. Pelatihan merupakan salah satu fungsi manajemen yang perlu dilaksanakan secara terus menerus dalam rangka pembinaan ketenagaan suatu organisasi. Pelatihan 
merupakan upaya investasi sumber daya manusia dalam sebuah lembaga. Menurut Mondy (2008) pelatihan adalah aktivitas-aktivitas yang dirancang untuk memberi para pembelajar pengetahuan dan keterampilan yang dibutuhkan untuk pekerjaan mereka saat ini. Armstrong (2009:67): Pelatihan adalah modifikasi perilaku sistematis melalui pembelajaran, yang terjadi sebagai hasil dari pendidikan, pengembangan pembelajaran, dan pengalaman yang direncanakan. Noe (2010:351) pelatihan merupakan upaya yang direncanakan oleh suatu lembaga pendidikan untuk mempermudah pembelajaran tentang kompetensikompetensi yang berkaitan dengan pekerjaan, yang meliputi pengetahuan, keterampilan, sikap dan perilaku. Langkah-langkah pelatihan menurut Pont (dalam Haris Mudjiman.2011) merupakan sebuah siklus kegiatan berkelanjutan yang terdiri dari: 1) analisis kebutuhan pelatihan, 2) perencanaan program pelatihan, 3) penyusunan bahan pelatihan, 4) pelaksanaan pelatihan, dan 5) penilaian pelatihan. Secara skematis siklus pelatihan sebagai berikut:

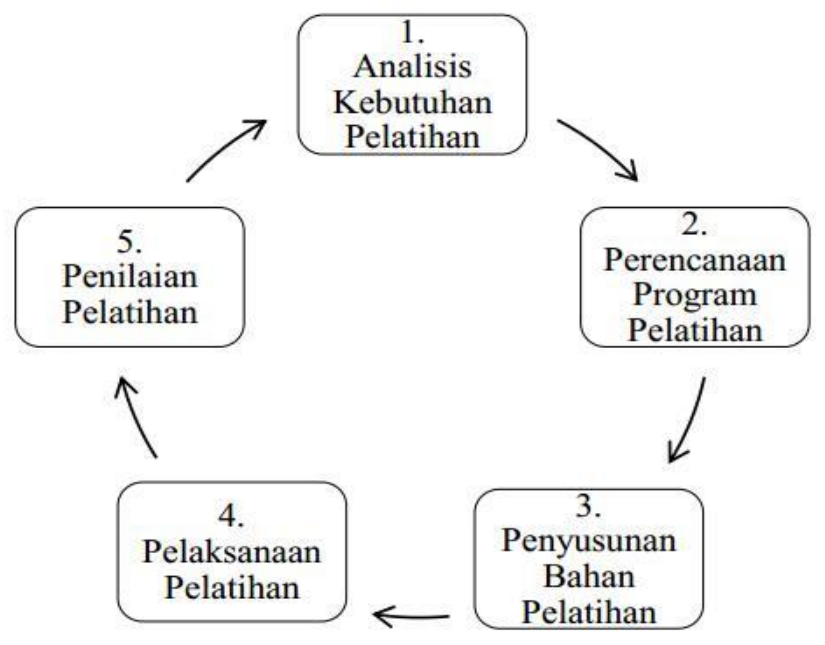

Gambar 1. Model Siklus Pelatihan (Haris Mudjiman: 2011)

Aspek kemampuan diri peserta pelatihan mencakup indikator: (1) pemahaman sistem dan cara kerja laptop, (2) penggunaan tool kit alat praktek dengan benar, (3) pemahaman skema diagram laptop,

(4) motivasi diri belajar secara aktif, (5) Inovasi dan kreativitas berfikir, (6) Peningkatan skill keterampilan dalam praktek (7) kemandirian. Aspek instruktur pelatihan mencakup indikator (1) konsep keilmuan (2) integritas, kesiapan, dan kesungguhan, Kesesuaian materi (4) kualitas interaksi (5) kreatif dan memotivasi suasana. Aspek monitoring dan evaluasi pelaksanaan pelatihan mencakup indikator : (1) tema pelatihan, (2) ketepatan waktu, (3) kualitas penerapan authentic assesment, (4) Kelengkapan materi, (5) Sikap penyelenggara, (6) feed back selama proses belajar, (7) Penyajian mudah dipahami. 


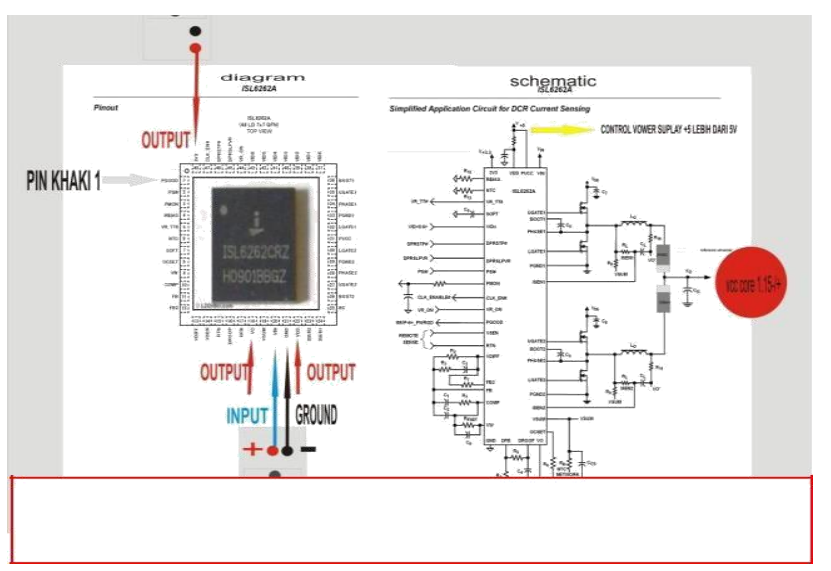

Gambar 2. Pemahaman skematik diagram

\section{Metode Penelitian}

Hasil akhir penelitian ini adalah berupa implementasi model pelatihan analisis pelacakan dan perbaikan laptop bagi Siswa SMK. Oleh karena itu penelitian ini menggunakan metode deskriptif kuantitatif. Kegiatan penelitian dilakukan pada bulan September 2016. Lokasi penelitian yang dipilih adalah di SMK Adi Sumarmo Colomadu dan SMK Muhammadiyah Karanganyar Propinsi Jawa Tengah dengan jumlah subjek penelitian sejumlah 20 responden. Teknik pengumpulan data yang digunakan adalah (1) observasi, (2) wawancara, (2) evaluasi kinerja praktek. Data yang diperoleh dilakukan analysis interactive model dari Miles dan Huberman (1994: 23) yang membagi kegiatan analisis menjadi beberapa bagian, yaitu: pengumpulan data, reduksi data, penyajian data dan penarikan kesimpulan. Desain materi pelatihan yang disampaikan pada SMK mitra berupa pembekalan kemampuan skill komputer dibidang laptop mencakup kegiatan sebagai berikut :
a. Analisis kerusakan mainboard akibat kerusakan atau kesalahan prosedur perbaikan.

b. Teknik analisis dan membaca skema pemahaman fungsi dan cara kerja rangkaian komponen motherboard laptop meliputi: distribusi power dan urutan sinyal power control, teknik inject tegangan, menentukan test point tanpa skema.

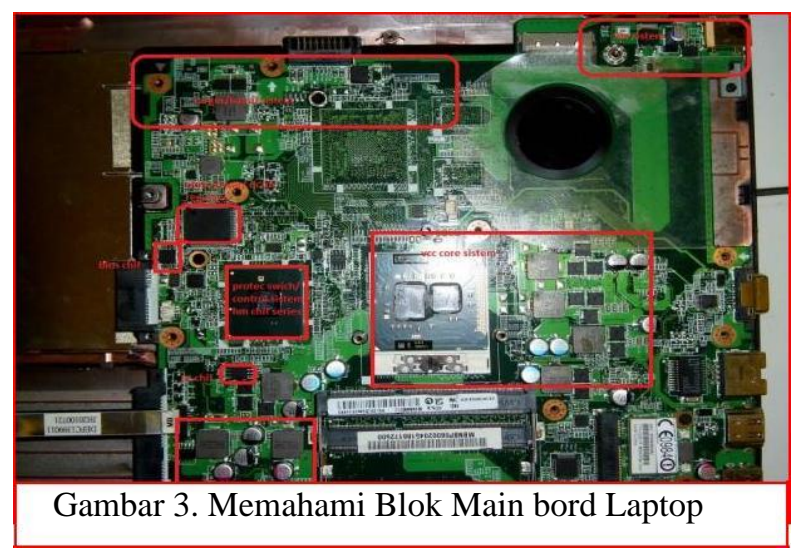

c. Cara mengukur komponen rusak dan mencari tahu komponen power yg rusak yg akan diganti / subtitusi serta membaca skema dan memahami datasheet.

d. Cara mengoperasikan alat servis dengan pengaturan temperatur yg tepat.

e. Troubleshooting mati total dan analisa tegangan pada motherboard laptop.

f. Teknik bongkar pasang BGA chipset laptop termasuk cara rebalingnya dan menentukan apakah BGA chips tersebut sudah rusak atau belum.

g. Cara memperbaiki BIOS rusak dan bios terpassword.

h. Teknik menurunkan temperatur VGA / BGA chipset.

i. Rahasia memperbaiki semua masalah yang sering terjadi pada berbagai merk laptop.

j. Cara cepat bongkar pasang super IO / embedded controller windbond ene nuvoton dan sejenisnya.

k. Teknik BIOS dan cara menginstal sistem operasi windows.

Evaluasi dilakukan untuk mengetahui tingkat efektivitas dan kebermanfaatan hasil pelatihan. Jenis evaluasi kegiatan pelatihan terdiri atas:1) Evaluasi teori yaitu berisi tentang respon tanya jawab yang berkaitan 
tentang materi yang telah diajarkan, 2) Evaluasi hasil terdiri atas unsur evaluasi kemampuan diri atau kinerja praktek (skill), evaluasi terhadap instruktur, dan evaluasi pelaksanaan kegiatan pelatihan. Terdapat 8 parameter untuk mengukur tingkat kinerja praktek selama proses pelatihan yaitu:

a.

b. Mampu melacak kerusakan pada LCD

c. Mampu melacak booting led nyala kemudian mati d. Mampu melacak power mati, saat charger dipasang lampu indikator berkedip

e. Mampu melacak kerusakan pada LCD kadang kadang berwarna putih atau mati setelah beberapa menit.

f. Mampu melacak kerusakan pada DVD atau optic tidak terdeteksi.

g. Mampu melacak kerusakan pada Wi-fi tidak dapat akses internet.

h. Mampu melacak kerusakan pada sistem operasi.

i. Mampu melacak kerusakan Laptop mati total

Implementasi model pelatihan untuk membangun kemampuan skill analisis pelacakan kerusakan dan perbaikan laptop bagi siswa SMK sebagai berikut :

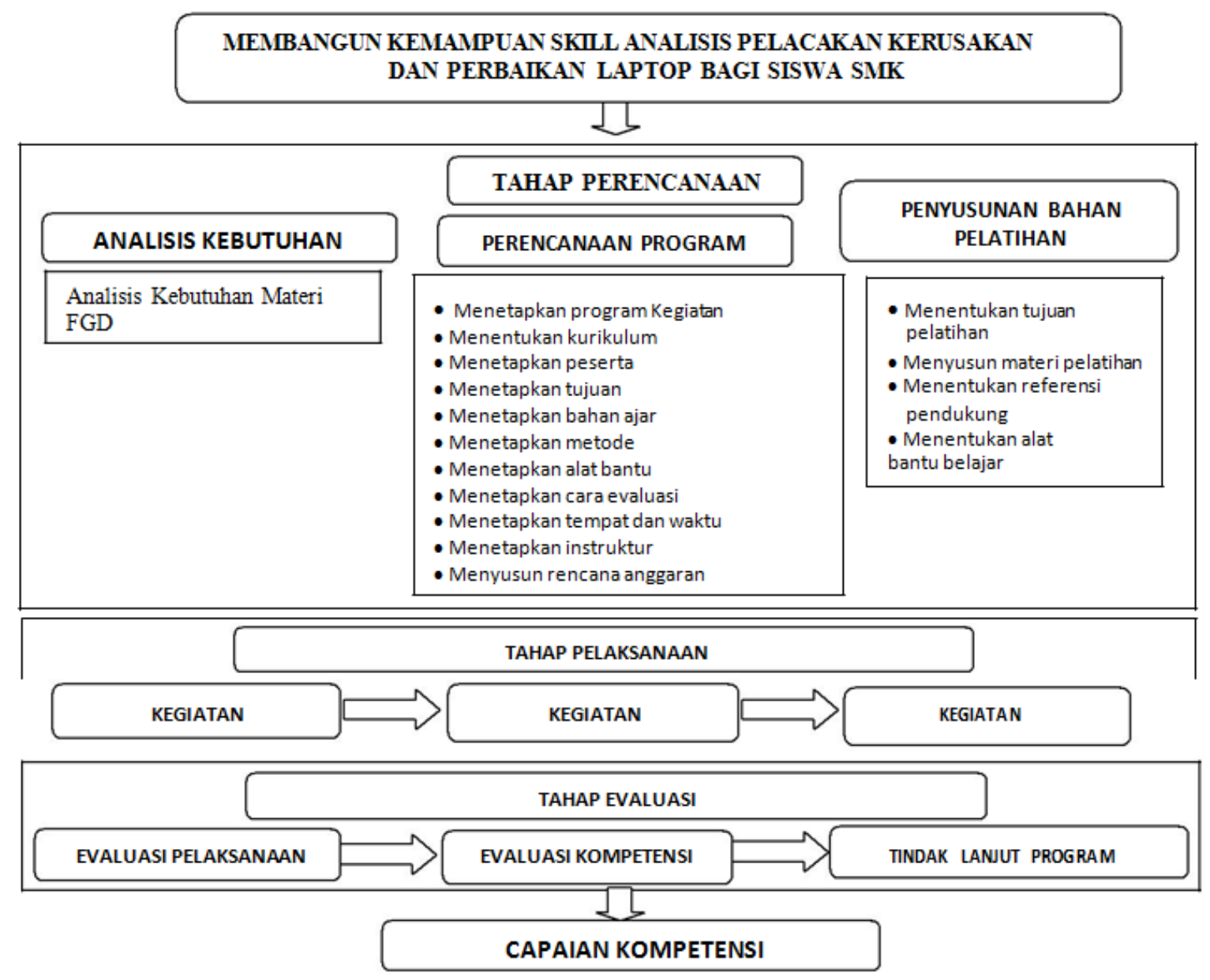

Gambar 4. Model Pelatihan Analisis Pelacakan dan Perbaikan Laptop Bagis Siswa SMK 


\section{Hasil Dan Pembahasan}

Evaluasi efektivitas pelaksanaan kegiatan pelatihan berdasarkan kriteria keberhasilan yang dicapai. Evaluasi ini berdasarkan hasil unjuk kerja praktek peserta selama mengikuti pelatihan, yang di lihat dari kemajuan peserta sejak pemahaman teori sampai kepada implementasi praktek yang sesungguhnya. Secara keseluruhan hasil pelaksanaan kegiatan pelatihan dapat berjalan dengan katagori baik. Hal ini dapat dilihat dari peran peserta pelatihan yang begitu antusias mengikuti setiap materi yang disampaikan. Walaupun terkendala oleh keterbatasan waktu, namun materi-materi pelatihan yang disampaikan dapat memberi manfaat yang besar terutama dapat meningkatkan kompetensi keahlian peserta diklat. Hal ini didukung oleh data empirik yang diperoleh selama kegiatan berlangsung berdasarkan hasil evaluasi selama mengikuti pelatihan. Data hasil evaluasi diperoleh sebagai berikut:

\section{Evaluasi Teori}

Pada evaluasi teori, dilakukan tanya jawab secara langsung mengenai troubleshooting, teknik pelacakan jenis kerusakan dan perbaikan, kebermanfaatan kegiatan. Berdasarkan hasil tanya dengan peserta, diperoleh respon yang baik. Para peserta memperoleh wawasan tentang analisis kerusakan mainboard, prosedur perbaikan, analisis membaca skema pemahaman fungsi, cara kerja rangkaian meliputi distribusi power dan urutan sinyal power control, teknik inject tegangan, menentukan test point, cara mengoperasikan alat servis, troubleshooting mati total, teknik bongkar pasang BGA chipset laptop, serta cara menginstal sistem operasi windows.

\section{Evaluasi Hasil}

Seluruh peserta mempunyai kesempatan yang sama dalam melakukan praktek secara individual/mandiri terhadap materi yang diajarkan.
Evaluasi terhadap hasil diperoleh melalui data kuantitatif. Data yang diungkap adalah berdasarkan 3 aspek penilaian hasil yaitu 1) Kemampuan diri (kinerja praktek/skill), 2) Penilaian instruktur pelatihan, 3) Monitoring dan evaluasi pelaksanaan kegiatan pelatihan.

Tabel 1. Aspek Kemampuan diri (Skill)

\begin{tabular}{llll}
\hline No & \multicolumn{1}{c}{ Aspek } & $\begin{array}{c}\text { Rerata } \\
\text { Skor }\end{array}$ & Keterangan \\
\hline 1. & $\begin{array}{l}\text { Pemahaman } \\
\text { sistem kerja } \\
\text { rangkaian }\end{array}$ & 3,5 & Baik \\
\hline 2 & $\begin{array}{l}\text { Penggunaan } \\
\text { tool kit alat } \\
\text { praktek secara } \\
\text { benar }\end{array}$ & 3,4 & Baik \\
\hline 3. & $\begin{array}{l}\text { Pemahaman } \\
\text { Troubleshooting }\end{array}$ & 3,8 & Baik \\
\hline 4. & $\begin{array}{l}\text { Motivasi belajar } \\
\text { aktif }\end{array}$ & 4,1 & Baik \\
\hline 5. & $\begin{array}{l}\text { Inovasi } \\
\text { kreativitas } \\
\text { berfikir }\end{array}$ & 3,8 & Baik \\
\hline 6. & $\begin{array}{l}\text { Keterampilan } \\
\text { praktek }\end{array}$ & 3,6 & Baik \\
\hline 7. & Kemandirian & 4,0 & Baik \\
\hline & Rerata & 3,7 & Baik \\
\hline
\end{tabular}

(Sumber: Data primer terolah: 2016

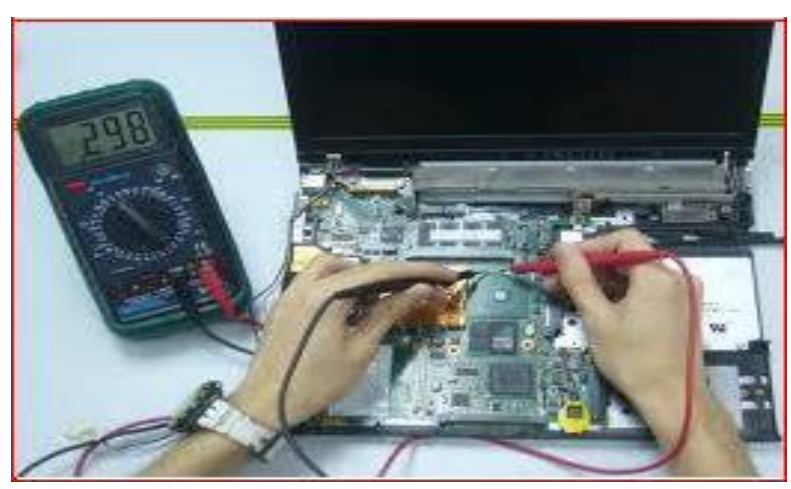

Gambar 5. Melacak Kerusakan dengan alat ukur

Berdasarkan Tabel 1. hasil evaluasi kemampuan peserta terhadap kegiatan pelatihan laptop menunjukkan rerata skor 3,7 atau $74,4 \%$. Artinya peserta pelatihan memiliki kemampuan skill yang baik. Evaluasi instruktur pelatihan sebagaimana Tabel 2. 
Tabel 2. Aspek penilaian instruktur pelatihan

\begin{tabular}{llcl}
\hline No & \multicolumn{1}{c}{ Aspek } & $\begin{array}{c}\text { Rerata } \\
\text { Skor }\end{array}$ & Keterangan \\
\hline 1. & $\begin{array}{l}\text { Konsep } \\
\text { keilmuan }\end{array}$ & 4,5 & Sangat Baik \\
\hline 2 & $\begin{array}{l}\text { Integritas cara } \\
\text { penyampaian }\end{array}$ & 4,1 & Baik \\
\hline 3. & $\begin{array}{l}\text { Kesesuaian } \\
\text { materi }\end{array}$ & 4,6 & Sangat Baik \\
\hline 4. & $\begin{array}{l}\text { Kualitas } \\
\text { interaksi }\end{array}$ & 3,9 & Baik \\
\hline 5. & $\begin{array}{l}\text { Kreatif dan } \\
\text { memotivasi } \\
\text { suasana. }\end{array}$ & 3,8 & Baik \\
\hline & Rerata & 4,2 & Sangat Baik \\
\hline
\end{tabular}

(Sumber: Data primer terolah: 2016)

Evaluasi terhadap instruktur pada Tabel 2 menggunakan skala $1 \quad-5$. skala tersebut menunjukkan penilaian instruktur pelatihan mencapai rerata skor 4,2 atau 83,2\% dalam kategori sangat baik. Evaluasi pelaksanaan pelatihan disajikan pada Tabel 3.
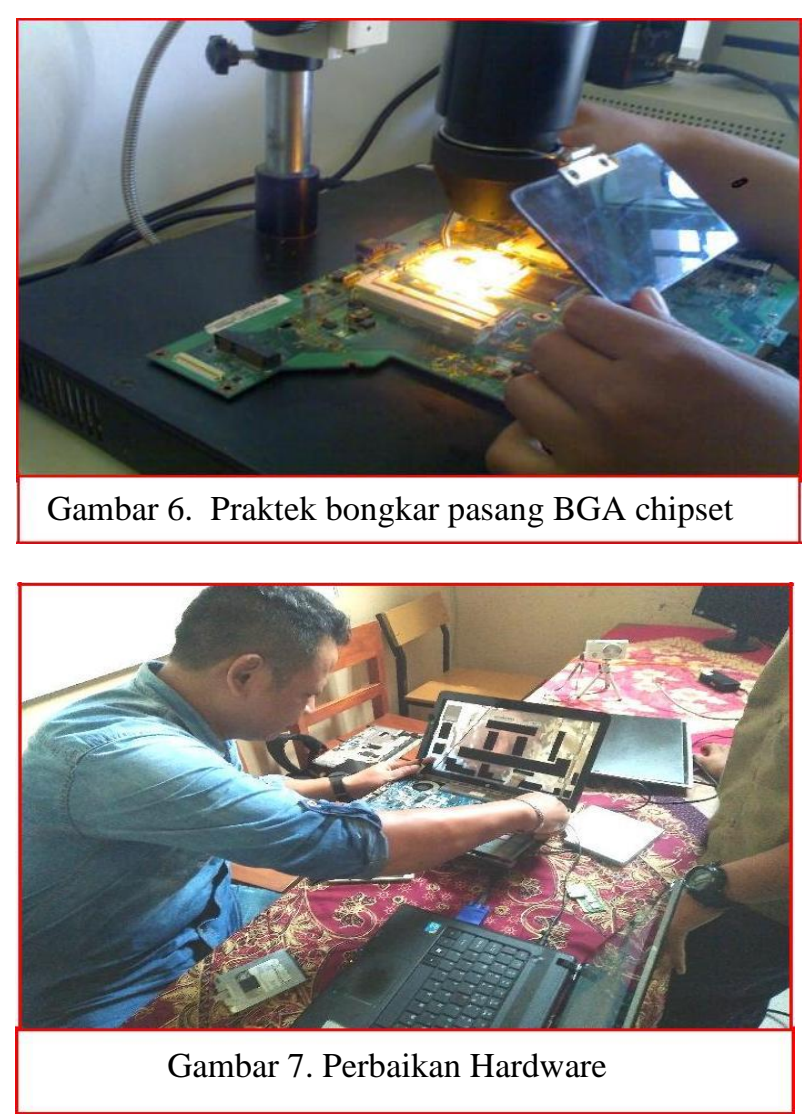

Tabel 3. Aspek Monitoring dan valuasi

\begin{tabular}{|c|c|c|c|}
\hline No & Aspek & $\begin{array}{l}\text { Rerata } \\
\text { Skor }\end{array}$ & Keterangan \\
\hline 1. & $\begin{array}{l}\text { Tema } \\
\text { pelatihan }\end{array}$ & 4,0 & Baik \\
\hline 2 & $\begin{array}{l}\text { Ketepatan } \\
\text { waktu }\end{array}$ & 3,3 & Baik \\
\hline 3. & $\begin{array}{l}\text { kualitas } \\
\text { penerapan } \\
\text { authentic } \\
\text { assesment, }\end{array}$ & 4,0 & Baik \\
\hline 4. & $\begin{array}{l}\text { Kelengkapan } \\
\text { materi }\end{array}$ & 3,9 & Baik \\
\hline 5. & $\begin{array}{l}\text { Sikap } \\
\text { penyelenggara }\end{array}$ & 4,3 & $\begin{array}{l}\text { Sangat } \\
\text { Baik }\end{array}$ \\
\hline 6. & $\begin{array}{l}\text { feed back } \\
\text { selama proses } \\
\text { belajar }\end{array}$ & 3,9 & Baik \\
\hline 7. & $\begin{array}{l}\text { Penyajian } \\
\text { mudah } \\
\text { dipahami } \\
\end{array}$ & 3,7 & Baik \\
\hline & Rerata & 3,9 & Baik \\
\hline
\end{tabular}

(Sumber: Data primer terolah: 2016)

Pada Tabel 3 menunjukkan monitoring dan evaluasi pelaksanaan pelatihan dalam skala $1-5$. Skala tersebut menun jukkan bahwa hasil pelaksanaan kegiatan pelatihan membangun kemampuan skill analisis pelacakan kerusakan dan perbaikan laptop bagi siswa SMK mencapai rerata skor 3,9 atau 77,1\% dalam kategori baik.

Pelaksanaan kegiatan pelatihan membangun kemampuan skill di bidang Hardware dan Software Melalui kemampuan analisis pelacakan kerusakan dan perbaikan laptop bagi siswa SMK dilaksanakan selama 18 jam tatap muka dan 17 jam penugasan yang diikuti oleh 20 siswa yang berasal dari SMK Adi sumarmo colomadu dan SMKN Muhammadiyah 3 Karanganyar. Pusat kegiatan pelaksanaan pelatihan ini bertempat di SMK Adi Sumarmo Colomadu Karanganyar dan didampingi oleh guru mata pelajaran elektronika dan komputer. Pelaksanaan kegiatan dibuka oleh Kepala sekolah SMK Adi Sumarmo Colomadu Karanganyar. Evaluasi capaian hasil kegiatan pelatihan ini dapat 
dilihat dari: 1). Respon dan antusias dari peserta pelatihan pada akhir kegiatan yang dilanjutkan dengan proses evaluasi terhadap

peserta. 2). Meningkatnya keterampilan kemampuan peserta pelatihan dalam memahami analisis pelacakan kerusakan sampai kepada skill dalam menangani perbaikan. Keterampilan (skill) peserta pelatihan diobservasi saat pelatihan berlangsung mulai dari persiapan sampai pada proses kegiatan diklat berlangsung.

Hasil pelaksanaan kegiatan pelatihan diperoleh temuan-temuan yaitu pada tahap persiapan, pihak sekolah (Kepala Sekolah dan guru mapel) menyambut baik dan antusias yang sangat tinggi. Mereka menyambut dengan baik kegiatan pelatihan ini yang bertemakan membangun kemampuan skill di bidang hardware dan software melalui kemampuan analisis pelacakan kerusakan dan perbaikan laptop bagi siswa SMK. Pada tahap pelaksanaan, Guru dan instruktur sangat serius dalam mendampingi mengikuti setiap langkah kegiatan peserta pelatihan secara runtut diawali dari materi dasar laptop, materi pengenalan alat praktek trouble shouting, pengenalan perangkat laptop, praktek Instalasi software, praktek prosedur penanganan kerusakan, praktek penggunaan alat ukur, praktek membuka LCD, praktek kerusakan mati total, praktek kerusakan DVD, praktek kerusakan keyboard, sampai pada kegiatan evaluasi pelaksanaan kegiatan. Selama kegiatan pelatihan berlangsung peserta pelatihan begitu antusias mengikuti serta merespon secara positif. Hal tersebut dinyatakan dari sikap dan aktivitas selama pelatihan berlangsung dalam bentuk feedback dan tanya jawab yang dilakukan secara interaktif antara instruktur dengan peserta pelatihan. Tempat pelaksanaan kegiatan Pelatihan berlokasi di salah satu ruang kelas. Sebelum pelaksanaan, tim pelatihan melakukan survey kesiapan ruangan, menyediakan fasilitas tool praktek, LCD proyektor serta jarngan instalasi listrik sehingga pada saat kegiatan, suasana sangat

kondusif untuk melakukan pelatihan.

Berdasarkan hasil kegiatan pelatihan yang telah dicapai didapatkan bahwa peserta pelatihan memiliki kemampuan serta potensi yang baik, terlihat dari kemampuan peserta pelatihan mampu menyelesaikan materi praktek yang dilakukan saat pelatihan berlangsung. Pihak Kepala sekolah menyambut dengan baik kegiatan pelatihan ini terutama dalam mendukung pembekalan sebagai penguatan kompetensi siswa SMK agar mampu bersaing di dunia usaha dan siap bekerja secara mandiri. Pihak sekolah berharap agar dapat diadakan kegiatan kegiatan sejenis di tahun-tahun selanjutnya.

Kemampuan diri (skill) peserta pelatihan menunjukkan mencapai rerata skor 3,7 atau 74,4\% dalam kategori baik. Bila diuraikan secara detail bahwa peserta pelatihan memiliki kemampuan dalam memahami sistem kerja rangkaian dengan baik mencapai rerata skor 3,5 atau $69 \%$. Peserta pelatihan mampu menggunakan tool kit praktek secara baik dan benar dengan rerata skor 3,4 atau $68 \%$. Peserta pelatihan memahami troubleshooting dengan baik mencapai rerata skor 3,8 atau $76 \%$. Peserta pelatihan memiliki motivasi belajar aktif dengan baik skor rerata 4,1 , atau $81 \%$. Peserta pelatihan memiliki inovasi kreativitas berpikir yang baik dengan rerata skor 3,8 atau $75 \%$. Keterampilan praktek yang dimiliki peserta pelatihan mencapai rerata skor 3,6 atau $72 \%$. Program Pelatihan ini sangat bermanfaat terutama dalam meningkatkan kemandirian dengan baik mencapai skor rata rata 4,0 atau $80 \%$. Secara keseluruhan pelaksanaan kegiatan pelatihan ini berlangsung secara baik mencapai rerata skor 3,9 
atau $77,1 \%$. Selain itu penilaian terhadap instruktur pelatihan sebagai nara sumber atau instruktur mencapai rerata skor 4,2 atau 83,2 \% dengan kategori sangat baik. Hal ini menunjukkan bahwa pelaksanaan kegiatan pelatihan berlangsung dengan sukses tanpa ada kendala yang berarti. Agenda kegiatan pelatihan dapat dilaksanakan menyesuaikan dengan kondisi kegiatan siswa SMK pasca ujian dan masa liburan sekolah.

\section{Simpulan dan Saran}

\section{Simpulan}

Simpulan dari penelitian ini antara lain bahwa implementasi model pelatihan laptop bagi siswa SMK, dapat membangun kemampuan skill dalam menangani sejumlah permasalahan diagnosis dan perbaikan laptop. Implementasi model pelatihan ini merupakan solusi yang tepat untuk menangani permasalahan yang telah diidentifikasi berdasarkan analisis kebutuhan. Serangkaian kegiatan ini setidaknya dapat mendidik masyarakat anak bangsa khususnya siswa SMK untuk dibekali kemampuan hardskill dan softskill dibidang keahlian teknisi Laptop. Mengantarkan peserta didik dapat menemukan jati diri dengan penuh percaya diri menjadi manusia yang berguna bagi kehidupan masyarakat. Dapat menciptakan kemampuan berpikir yang aktif, kreatif dan inovatif. Pada masa yang akan datang, pemberdayaan masyarakat dibidang peningkatan kemampuan hardskill dan softskill dapat terus ditindaklanjuti, dalam upaya menciptakan lapangan kerja secara mandiri. Hasil evaluasi kegiatan program pelatihan skill pelacakan kerusakan dan perbaikan laptop dapat memberikan manfaat yang sangat berarti dan signifikan untuk menciptakan lulusan SMK yang berkompeten dan siap bersaing di dunia kerja. Semoga implementasi model pelatihan ini, menjadi awal yang baik untuk berani menatap masa depan yang lebih baik dengan terus meningkatkan kemampuan diri dan tentunya perlu adanya campur tangan dan dukungan dari pihak pemerintah, swasta maupun perguruan tinggi.

\section{Saran}

Berdasarkan hasil evaluasi, penguatan kompetensi praktek analisis dan perbaikan laptop perlu pengayaan yang direkonstruksi dalam kurikulum SMK terutama untuk membentuk kompetensi lulusan siswa SMK yang mandiri dan siap terjun di dunia kerja khususnya jurusan Elektronika dan Komputer.

\section{Daftar Pustaka}

Affandi, A. (2013). Portal Mint. Retrieved from Perangkat Keras Komputer: http://www.mint.web.id/

Alamsyah. (2013). Informatika. Retrieved from Physical Data Model:http://alamsyahinformatika.blogspot.com/

Alfiyanto, B. (2013). Pengujian Perangkat Lunak. Retrieved from Pengujian Perangkat Lunak: http://bagusalfiyanto.blogspot.com

Doni Kurniawan. (2008). Merawat dan Memperbaiki Notebook, Jakarta: Kawan Pustaka.

HarisMudjiman. 2011. Manajemen Pelatihan berbasis Belajarmandiri.Yogyakarta: Pustaka Pelajar

HarisMudjiman. 2011. BelajarMandiri:

Pembekalan dan Penerapan. Surakarta: Universitas Sebelas Maret Press.

Jogiyanto. (2000). Analisis dan Desain Sistem Informasi, Yogyakarta: Andi.

Komputer, G. (2013, 11 19). Global Komputer. Retrieved from Entity Relational Diagram: http://www.globalkomputer.com/home

Mulyono, Hasyim.(2008). Buku Pintar Komputer, Jakarta: Kriya Pustaka.

Milles, M.B \& A.M. Huberman. (1994). Qualitative data analysis. California: SAGE Publications Inc.

Nazaruddin, Ramdni.(2007). Komputer dan troubleshooting, Bandung: Informatika. 
Noe, Raymond. A. (2010). Manajemen Sumber Daya Manusia Mencapai Keunggulan Bersaing.NY: McGraw-Hill

Snelbecker. E. Glenn. 1974. Learning Theory, Instructional Theory and Psycho educational Design. New York: McGrawHill.
Tri, Endah, Utami.(2008). Merawat dan Memperbaiki Laptop Untuk Orang Awam, Yogyakarta: Pustaka Widyatama.

Yani, Ahmad.(2005). Panduan Menjadi Teknisi Komputer, Jakarta: PT Kawan Pustaka 